
\title{
$\begin{array}{ll}\text { Research Square } & \text { Preprints are preliminary reports that have not undergone peer review. } \\ \text { They should not be considered conclusive, used to inform clinical practice, } \\ \text { or referenced by the media as validated information. }\end{array}$
}

\section{Single Extreme Strong Sequence Can Offset Decades of Shoreline Retreat by Sea-level Rise}

\author{
Mitchell Harley ( $\nabla$ m.harley@unsw.edu.au ) \\ UNSW Sydney https://orcid.org/0000-0002-1329-7945 \\ Gerd Masselink \\ University of Plymouth \\ Amaia Ruiz de Alegría-Arzaburu \\ Universidad Autónoma de Baja California \\ Nieves Valiente \\ UNSW Sydney https://orcid.org/0000-0003-1716-0767 \\ Tim Scott \\ UNSW Sydney
}

\section{Article}

Keywords: Shoreline Retreat, Sea-level Rise, coastal forecasts

Posted Date: August 23rd, 2021

DOI: https://doi.org/10.21203/rs.3.rs-805900/v1

License: (c) (i) This work is licensed under a Creative Commons Attribution 4.0 International License.

Read Full License

Version of Record: A version of this preprint was published at Communications Earth \&amp; Environment on May 12th, 2022. See the published version at https://doi.org/10.1038/s43247-022-00437-2. 


\section{Abstract}

Extreme storms cause extensive beach-dune erosion and are universally considered to enhance coastal erosion due to sea-level rise (SLR). However, extreme storms can also have a positive contribution to the nearshore sediment budget by exchanging sediment between the lower and upper shoreface and/or between adjacent headlands, potentially mitigating adverse SLR impacts. Here we use three highresolution morphological datasets of extreme storm-recovery sequences from Australia, the UK and Mexico to quantify the nearshore sediment budget and relate these episodic volume changes to long-term coastal forecasts. We show that sediment gains over the upper shoreface and beach were very significant $\left(58-140 \mathrm{~m}^{3} / \mathrm{m}\right)$ and sufficient to offset decades of predicted shoreline retreat due to SLR, even for an upper SSP5-8.5 scenario. It is evident that increased confidence in shoreline predictions due to SLR relies fundamentally on robust quantitative understanding of the sediment budget, in particular any long-term contribution of sediment transport from outside the nearshore region.

\section{Introduction}

Climate change is likely to cause a global sea-level rise (SLR) by 2100 of $0.63-1.01 \mathrm{~m}$ based on an upper SSP5-8.5 scenario ${ }^{1}$. Combined with ambient trends in shoreline dynamics, SLR under this scenario is forecast to result in the significant retreat or loss of almost half of the world's sandy beaches by the end of this century ${ }^{2}$. Climate change is also expected to cause increases in extreme wave heights along almost three fifths of the world's coastline by $2100^{3}$, but the long-term (> 50 years) impact of extreme storms on coastal recession is ambiguous. Increased storminess is generally assumed to exacerbate coastal erosion due to SLR; however, short-to-medium term (years-decades) shoreline variability caused by storms is generally considered noise over long time scales when shoreline change is mainly driven by $\mathrm{SLR}^{4}$. On the other hand, extreme storms can transport sediment into the nearshore zone from elsewhere, for example from the lower shoreface ${ }^{5}$, potentially tempering long-term erosion by $\operatorname{SLR}^{6,7}$.

Coastal erosion and shoreline retreat as a result of extreme storm activity is particularly apparent on the upper beach as storm waves leave beaches depleted and coastal dunes scarped, with typical beach-dune sediment losses of 50-150 $\mathrm{m}^{3}$ per unit meter beach width ${ }^{8-10}$. A suite of cross-shore and longshore sediment transport pathways are responsible for these morphological changes, summarized in Fig. 1. The vast majority of sediment transport pathways during both extreme and non-energetic (i.e., modal) wave conditions, however, merely redistribute sediment across the upper shoreface, i.e., landward of the depth of closure (DoC), defined as the depth beyond which no detectable morphological change occurs over a given time frame ${ }^{11-13}$. Sediment exchange between the upper and lower shoreface across the DoC can play a significant role in long-term shoreline change, and of particular interest here is the wave-driven onshore sediment transport driven by disequilibrium shoreface morphology $y^{5,7}$.

Geological evidence from Australia strongly suggests that low-magnitude onshore sediment transport $O\left(1 \mathrm{~m}^{3} / \mathrm{m} / \mathrm{yr}\right)$ from the lower shoreface to the beach has been responsible for extensive coastal 
progradation when sea level was relatively stable during the second part of the Holocene ${ }^{14-16}$ (see also ${ }^{17,1817,18}$ examples from Brazil ${ }^{17}$ and The Netherlands $\left.{ }^{18}\right)$. Under the influence of rising sea level, this component, which results in a lowering of the lower shoreface ${ }^{19}$, has the potential to offset, or even overturn, the impact of sea-level rise ${ }^{20}$. As the source of this sediment is beyond the depth of closure, it is highly likely that energetic wave conditions are implicated in this transport as modal waves are not expected to be able to move sediments at such depths. Net shoreface sand supply to beaches may be a widespread and common, but little appreciated factor in coastal stability ${ }^{21,22}$. Likewise, sediment from adjacent beaches and mobilised during extreme storms (e.g. headland sand bypassing) may provide an additional source of sediment to the nearshore region ${ }^{23}$.

This paper presents three unique coastal morphological data sets from different continents that each encompass a sequence of an extreme storm or extended storm cluster followed by a milder period of beach recovery. Despite the morphological data being collected beyond the theoretical DoC, sediment budget analysis unequivocally points towards unbalanced sediment budgets at all three sites, demonstrating in these cases significant sediment gains within the upper shoreface over the stormrecovery sequence. We show that these short time-scale events can have very significant implications for long-term coastal evolution, potentially offsetting the impacts of upper limits (SSP-8.5) of predicted sealevel rise by several decades.

\section{Results}

Figures 2-4 summarize long-term and extreme storm sequence results at three high-resolution coastal monitoring locations in Australia, the UK and Mexico. These three locations are: (1) the $3.6 \mathrm{~km}$-long Narrabeen embayment in SE Australia (Fig. 2), comprising one of the longest (> 40 years, monthly) subaerial beach survey programs worldwide ${ }^{24}$; (2) the 3-km long Perranporth embayment in SW England (Fig. 3), where subaerial beach surveys have been undertaken monthly since $2006^{25}$; and (3) the opencoast La Mision Beach in NW Mexico (Fig. 4), where a 2.2-km stretch of sandy coast has been monitored monthly since 2015. Each site is characterized as wave-dominated (average $\mathrm{H}_{\mathrm{s}} \approx 1.6 \mathrm{~m}$ at all three sites), sandy $\left(D_{50} \approx 0.3-0.4 \mathrm{~mm}\right)$ and of moderate upper shoreface steepness ( $\left.\tan \beta \approx 0.03-0.04\right)$. The tidal regimes at Narrabeen and La Mision are microtidal (spring tidal range $=1.3$ and $2.3 \mathrm{~m}$, respectively), whereas Perranporth is macrotidal (spring tidal range $=6.3 \mathrm{~m}$ ).

Complementing the continuous subaerial beach measurement records were detailed three-dimensional surveys of the entire upper shoreface at time intervals prior to, immediately following and approximately 12 months after an extreme storm event or extended storm cluster. At Narrabeen, an extreme east coast low storm impacted the coast in June 2016 that resulted in the largest subaerial beach erosion (average $=121 \mathrm{~m}^{3} / \mathrm{m}$ ) over four decades ${ }^{26}$. At Perranporth, a cluster of extratropical cyclones over successive boreal winters between 2013 and 2016 caused an average of $212 \mathrm{~m}^{3} / \mathrm{m}$ of subaerial beach erosion, with the 2013/2014 winter period in particular considered the most energetic winter period since at least $1948^{10}$. At La Mision, a similar sequence of extratropical storms concentrated over the 2018/2019 boreal 
winter caused the most severe winter erosion (average $=208 \mathrm{~m}^{3} / \mathrm{m}$ ) since measurements at the site began (Fig. 4b). Each three-dimensional survey extended from the upper beach to beyond the theoretical DoC over the respective storm sequences, calculated (see Methods) as - $11.6 \mathrm{~m}$ (Narrabeen), - $19.3 \mathrm{~m}$ (Perranporth) and - $9.1 \mathrm{~m}$ (La Mision), all referenced to mean sea level (MSL).

The morphological response from all three storm sequences indicates patterns of extensive erosion along the subaerial beach coupled with adjacent sediment deposition in the shallow subaqueous zone. Representative cross-shore transects (Figs. 2g, $3 \mathrm{e}$ and 4 e) show these deposition zones are characterized by pronounced storm bar morphology with bar crests between approximately $200 \mathrm{~m}$ offshore for the microtidal Narrabeen site and $700 \mathrm{~m}$ for the macrotidal Perranporth site. Pivot points separating areas of upper-shoreface storm erosion and deposition are observed at depths relative to MSL of approximately $2.8 \mathrm{~m}$ (Narrabeen), -6 m (Perranporth) and - $1.2 \mathrm{~m}$ (La Mision). In the subsequent recovery phase, eroded sediment stored in the storm bar returns under more modal wave conditions, and the patterns of storm erosion and deposition are mostly reversed. At lower depths, profile variability displays the characteristic 'pinching' towards the theoretical DoC that is typical of the upper shoreface, although seabed variability outside of the survey error $(\sim 0.14 \mathrm{~m})$ is still evident at these lower depths.

Integrating these observations over the upper shoreface and beach, whilst carefully considering survey error (refer Methods), reveals that the overall sediment balances are not closed and all three locations record significant net sediment gains (Fig. 5). Average net gains per unit meter beach width range from + $58 \mathrm{~m}^{3} / \mathrm{m}$ (La Mision) to $+140 \mathrm{~m}^{3} / \mathrm{m}$ (Perranporth), which are comparable in magnitude to the extreme erosion observed over the subaqueous beach during each storm sequence. In absolute terms, within the survey areas spanning several kilometres, these sediment gains equate to $+130000 \mathrm{~m}^{3}$ of sediment ( $\mathrm{La}$ Mision), $+400000 \mathrm{~m}^{3}$ (Narrabeen) and $+420000 \mathrm{~m}^{3}$ (Perranporth). While the direct source of these sediment gains cannot be conclusively ascertained without detailed process-based measurements and tracer experiments, the alongshore variability and phasing of these net gains provide some insight. At Narrabeen, sediment gains occur primarily in the storm phase and are strongly skewed towards the southern half of the embayment (max. net gain $=+392 \mathrm{~m}^{3} / \mathrm{m}$ ). This is consistent with likely counterclockwise beach rotation (Transport Pathway 3 in Fig. 1) caused by this anomalous easterly storm ${ }^{26,27}$, but also coincides with the region of the rocky embayment where deeper sand bodies are more abundant, suggesting onshore sediment transport from the lower to upper shoreface (Pathway 6). At Perranporth, sediment gains occur instead primarily over the recovery phase and particularly at the southern half (max. net gain $=+271 \mathrm{~m}^{3} / \mathrm{m}$ ), which might be related to alongshore headland sand bypassing input at the southern extremity (Pathway 1 ) under less-extreme 'recovery winters' ${ }^{23}$. Similar to Narrabeen, sediment gains at La Mision occur primarily over the storm phase, but unlike the embayed Narrabeen and Perranporth sites, shows no obvious alongshore bias (max. gain $=+309 \mathrm{~m}^{3} / \mathrm{m}$ ). Possible sediment sources for these net gains include onshore sediment transport from lower shoreface sand storages (Pathway 6), as well as winter fluvial discharges from the nearby tidal inlet (Pathway 7). 
Using the Bruun rule approach ${ }^{20}$, the observed sediment gains over the entire upper shoreface and beach may be characterized in terms of equivalent years of theoretical shoreline retreat due to SLR over the entire 21 st Century (2000-2100). Figure 5b shows that the annual rate of sediment input required to offset SLR recession $\left(Q_{\text {offset }}\right)$ is a function of the upper shoreface width $W^{*}$, defined as the horizontal distance the subaerial beach berm to the theoretical DoC. Here we use the long-term DoC derived from 41 years of wave reanalysis data (see Methods), rather than over the DoC calculated over the shorter-term storm-sequence as above ${ }^{28}$. For Narrabeen, the narrower upper shoreface width (long term DoC $=-14.3 \mathrm{~m}$, $\mathrm{W}^{*}=480 \mathrm{~m}$ ) means that this offset rate equates to $3.7 \mathrm{~m}^{3} / \mathrm{m} /$ year for an upper SSP5-8.5 SLR scenario between 2000 and 2100, compared to 6.2 and $8.4 \mathrm{~m}^{3} / \mathrm{m} /$ year for the deeper and wider La Mision and Perranporth upper shorefaces (long term DoC $=-18.2 \mathrm{~m}$ and $-20.2 \mathrm{~m}, \mathrm{~W}^{*}=810 \mathrm{~m}$ and $1090 \mathrm{~m}$ for La Mision and Perranporth, respectively). Based on these annual rates, the observed sediment gains over the extreme storm-recovery sequence at Narrabeen are equivalent to 25 years of theoretical SLR recession that may be offset at the upper SSP5-8.5 scenario, or 43 years for the more sustainable SSP1-26. SLR scenario. At Perranporth and La Mision, these offset values equate to 18 and 9 years for SSP5-8.5 SLR, or 31 and 16 years for SSP1-2.6, respectively.

\section{Discussion}

Our results based on unique high-resolution field measurements over three extreme storm-recovery sequences from three different continents highlight the present major challenges of predicting long-term coastal evolution over planning horizons of decades to centuries. Despite its many assumptions and shortcomings ${ }^{29}$, the Bruun rule has emerged as the most widely used approach for predicting shoreline change due to SLR over decades to century timescales, especially for localized coastal hazard assessments $^{30}$ and global studies ${ }^{2}$. Application of the Bruun rule involves a simple upward and backward translation of a cross-shore beach profile to a location where the volumetric losses from the upper part of the profile are matched by gains across the lower part. Net sediment gains and losses can be included in the Bruun rule ${ }^{20}$, but their inclusion is simplified to steady (e.g., annual) sediment fluxes based on long-term sediment budgets and do not consider substantial and episodic sediment fluxes due to extreme storm-recovery sequences. The significant magnitudes of sediment input $\left(O\left(100 \mathrm{~m}^{3} / \mathrm{m}\right)\right)$ observed in this study over short time-scales provide strong evidence as to the limitations of the Bruun rule approach (and other simplified shoreface equilibrium approaches ${ }^{7,14}$ ) in neglecting these fluxes. This is particularly in light of robust projections pointing towards an increase in extreme waves globally, implying an exacerbation of episodic major sediment exchange at the lower shoreface or alongshore, that could amount to a cascading of model errors in long-term predictions.

While each of the three datasets show net positive sediment contributions, equally plausible are extreme storm sequences that cause significant losses to the overall sediment budget (e.g., imbalances in Pathways 1, 7, 8 and 9 in Fig. 1). Short-term sediment fluxes between the lower and upper shoreface (across the DoC) and from adjacent beaches reflect complex interactions between sediment transport processes, sediment storage (both on the lower shoreface and at adjacent beaches) and accommodation 
space on the upper shoreface. As outlined in a recent review of shoreface morphodynamics ${ }^{31}$, the present conceptual understanding of sediment transport on the lower shoreface is extremely limited. This is due to a combination of many factors, including: subtle imbalances between onshore and offshore-directed sediment fluxes; the dominance of bed load and gravity flows at these depths; the presence of migrating bedforms; a paucity of field data measurements beyond the surf zone; and uncertainties associated with up-scaling short-term measurements and process understanding to longer time-scales. These limitations are compounded by the severe lack of any knowledge of the seabed composition on the lower shoreface, with estimates suggesting that $71 \%$ of ocean depths between the $0 \mathrm{~m}-200 \mathrm{~m}$ depth contours remain completely unchartered ${ }^{32}$.

Predicting the potential fate of coastal environments out to the year 2100 and beyond, i.e., forecasting the 2100 coastline, is one of the most pressing challenges facing coastal science today. While it is unlikely that a step-change in our ability to model sediment transport at and between the lower and upper shoreface will be achieved in the near future, significant improvements in long-term predictions can be realised through: (1) a major upscaling of seabed mapping efforts (e.g., ${ }^{33,34}$ ), to evaluate the magnitude of sediment presently stored on the lower shoreface; and (2) a significantly greater number of routine monitoring efforts of entire nearshore systems appropriate for quantifying sediment fluxes. These two steps can greatly help identify both short and long-term changes to sediment budgets and their connectivity between lower and upper shoreface (including dunes), and between adjacent embayments, as well as provide early warning for coastal communities of any large-scale sediment shifts to SLR in the coming decades. Improvements in remote sensing technology (e.g., satellite-derived bathymetry ${ }^{35}$ ) are also likely to complement shoreface monitoring efforts, by providing regional perspectives on entire sediment compartments and their linkages ${ }^{36}$. The vertical accuracies of these technologies are still however limited $\left(\sigma_{v}>0.4 \mathrm{~m}\right)$, re-emphasising the need for enhanced traditional in-situ monitoring strategies $^{37}$.

\section{Methods}

\section{Multimethod morphological surveys}

Morphological surveys at each of the three locations were undertaken using a combination of survey methods to ensure seamless digital elevation models (DEM) spanning the subaerial and subaqueous beach system. At Narrabeen, subaerial beach surveys were undertaken using Airborne Lidar and Uncrewed Aerial Vehicles (UAVs), with vertical uncertainty $\left(\sigma_{\mathrm{v}}\right)$ quantified for this site and equipment as $0.11 \mathrm{~m}^{38}$ and $0.07 \mathrm{~m}^{39}$, respectively. At Perranporth, subaerial beach surveys were undertaken using a combination of Airborne Lidar $\left(\sigma_{\mathrm{v}}=0.15 \mathrm{~m}\right)$ and either UAV $\left(\sigma_{\mathrm{v}}=0.06 \mathrm{~m}\right.$ at this site) or RTK-GNSS mounted to an ATV $\left(\sigma_{v}=0.05 \mathrm{~m}\right)^{23}$. At La Mision, subaerial beach surveys were undertaken by walking RTK-GNSS $\left(\sigma_{\mathrm{v}}=0.05 \mathrm{~m}\right)$ at $50-\mathrm{m}$ spaced cross-shore transects. At all three sites, subaqueous surveys were undertaken using a single beam echosounder mounted on a boat (Perranporth, $\sigma_{v}=0.05 \mathrm{~m}$ ) or jetski (Narrabeen and La Mision, $\sigma_{v}=0.10 \mathrm{~m}$ ). These depth soundings were collected near-continuously along 
cross-shore transects spaced every $50 \mathrm{~m}$ at Narrabeen and Perranporth, or every $150 \mathrm{~m}$ at La Mision. At Perranporth, surveys were also complemented in deeper water $(<-10 \mathrm{~m})$ by multibeam echosounder $\left(\sigma_{\mathrm{v}}=\right.$ $0.06-0.30 \mathrm{~m})^{23}$. Seamless DEMS were subsequently created from the multimethod surveys using cubic interpolation. This method was found to best represent natural beach variability (e.g., intertidal bars) in the small data gaps ( $<30 \mathrm{~m}$ cross-shore) between subaerial and subaqueous measurements found at the microtidal Narrabeen and La Mision sites.

\section{Sediment budget error analysis}

DEMs of Difference (DoD), characterizing spatial variability in beach elevation change at each site, were calculated from the individual DEMs described above. Sediment budget error analyses were calculated following the approach of ${ }^{40}$, by first considering the limit of detection (LoD) for each DEM grid point:

$$
L O D=\sqrt{\sigma_{D E M 1}^{2}+\sigma_{D E M 2}^{2}}
$$

where $\sigma_{\mathrm{DEM}}$ is is the vertical uncertainty at each grid point depending on the localized survey method. The overall volume change $\Delta \mathrm{V}$ and associated uncertainty for each DoD were then calculated by considering only statistically-significant (95\% confidence level) morphological change above the limit of detection $\left(\left|Z_{\text {DEM1 }}-Z_{\text {DEM2 }}\right|>L o D\right)$. These overall volume changes $\Delta \mathrm{V}$ were then normalized per unit beach width based on the number of cross-shore transects in the survey region.

\section{Equivalent years of SLR offset}

Volumetric changes to the sediment budget caused by the three storm sequences were converted to equivalent years of SLR offset over the $21^{\text {st }}$ Century when estimated using the simple Bruun rule approach. Upper shoreface widths $W^{*}$ were calculated at each site considering the alongshore-averaged horizontal distance between the subaerial beach berm and the long-term DoC, which is calculated relative to mean low water as ${ }^{12,41}$ :

$$
D o C=2.28 H_{e, t}-68.5\left(\frac{H_{e, t}{ }^{2}}{g T_{e, t}^{2}}\right)
$$

where $H_{e, t}$ is the significant wave height exceeded 12 hours every $t$ years and $T_{e, t}$ the associated wave period. Following other SLR estimates using the Bruun rule (e.g. ${ }^{2,28}$ ), ERA5 wave reanalysis data ${ }^{42}$ spanning 41 years (1979-2020) was used to calculate the long-term DoC at each site. These values relative to mean low water were then converted to MSL considering the tidal range. The annual rate of sediment input required to offset SLR recession $\left(Q_{\text {offset }}\right)$ is subsequently calculated by: 


$$
Q_{\text {offset }}=\frac{\Delta S L R}{\Delta T} W^{*}
$$

where $\triangle$ SLR is the predicted median change in sea-level over the $21^{\text {st }}$ Century ${ }^{1}$ ( $\Delta$ SLR $=0.44 \mathrm{~m}$ and $0.77 \mathrm{~m}$ for SSP1-2.6 and SSP5-8.5 scenarios for 2000-2100, respectively) and T the time period in years $(\Delta T=100$ years). The equivalent years of SLR offset is then calculated by dividing the volumetric changes $\Delta \mathrm{V}$ by $\mathrm{Q}_{\text {offset }}$.

\section{Declarations}

\section{Data Availability}

The data that support the findings of this study are available from the corresponding author upon reasonable request. The Narrabeen-Collaroy survey program data is available at http://narrabeen.wrl.unsw.edu.au/.

\section{Acknowledgements}

This study was supported by the Australian Research Council (Grant \#DP150101339), the UK Natural Environment Research Council (Grant NE/M004996/1; BLUE-coast project) and CONACyT (CB-2014238765 and INFR-2013-011005). The authors would like to acknowledge all participants that contributed to the collection of the survey data.

\section{Author Contributions}

M.D.H and G.M. conceptualized the study and led the writing of the manuscript. M.H. led the survey data collection at Narrabeen and undertook the data analyses at Narrabeen and La Mision. G.M., N.V. and T.S. led the survey data collection at Perranporth. A.R.A-A led the survey data collection at La Mision. All authors contributed to the writing of the manuscript.

\section{References}

1. Fox-Kemper, B. et al. Ocean, Cryosphere and Sea Level Change. in Climate Change 2021: The Physical Science Basis. Contribution of Working Group I to the Sixth Assessment Report of the Intergovernmental Panel on Climate Change (eds. Masson-Delmotte, V. et al.) (Cambridge University Press).

2. Vousdoukas, M. I. et al. Sandy coastlines under threat of erosion. Nature Climate Change 10, 260-263 (2020).

3. Meucci, A., Young, I. R., Hemer, M., Kirezci, E. \& Ranasinghe, R. Projected 21st century changes in extreme wind-wave events. Science Advances 6, 1-10 (2020). 
4. Vitousek, S., Barnard, P. L., Limber, P., Erikson, L. \& Cole, B. A model integrating longshore and cross-shore processes for predicting long-term shoreline response to climate change. Journal of Geophysical Research: Earth Surface 122, 782-806 (2017).

5. Kinsela, M. A., Daley, M. J. A. \& Cowell, P. J. Origins of Holocene coastal strandplains in Southeast Australia: Shoreface sand supply driven by disequilibrium morphology. Marine Geology 374, 14-30 (2016).

6. Cowell, P. J., Thom, B. G., Jones, R. A., Everts, C. H. \& Simanovic, D. Management of uncertainty in predicting climate-change impacts on beaches. Journal of Coastal Research 22, 232-245 (2006).

7. Aagaard, T. \& Hughes, M. G. Equilibrium shoreface profiles: A sediment transport approach. Marine Geology 390, 321-330 (2017).

8. Castelle, B., Bujan, S., Ferreira, S. \& Dodet, G. Foredune morphological changes and beach recovery from the extreme 2013/2014 winter at a high-energy sandy coast. Marine Geology 385, 41-55 (2017).

9. Harley, M. D. et al. Extreme coastal erosion enhanced by anomalous extratropical storm wave direction. Scientific Reports 1-9 (2017) doi:10.1038/s41598-017-05792-1.

10. Masselink, G. et al. Extreme wave activity during 2013/2014 winter and morphological impacts along the Atlantic coast of Europe. Geophysical Research Letters 43, 2135-2143 (2016).

11. Udo, K., Ranasinghe, R. \& Takeda, Y. An assessment of measured and computed depth of closure around Japan. Scientific Reports 10, 1-8 (2020).

12. Hallermeier, R. J. A profile zonation for seasonal sand beaches from wave climate. Coastal Engineering 4, 253-277 (1981).

13. Valiente, N. G., Masselink, G., Scott, T., Conley, D. \& McCarroll, R. J. Role of waves and tides on depth of closure and potential for headland bypassing. Marine Geology 407, 60-75 (2019).

14. Cowell, P. J., Roy, P. S. \& Jones, R. A. Simulation of large-scale coastal change using a morphological behaviour model. Marine Geology 126, 45-61 (1995).

15. Thom, B. G. Transgressive and regressive stratigraphies of coastal sand barriers in southeast Australia. Marine Geology 56, 137-158 (1984).

16. Oliver, T. S. N. et al. Holocene evolution of the wave-dominated embayed Moruya coastline, southeastern Australia: Sediment sources, transport rates and alongshore interconnectivity. Quaternary Science Reviews 247, 106566 (2020). 
17. Dillenburg, S. \& Hesp, P. A. Geology and Geomorphology of Holocene Coastal Barriers of Brazil. (Springer-Verlag Berlin Heidelberg, 2009).

18. Beets, D. J. \& van der Spek, A. J. F. The Holocene evolution of the barrier and the back-barrier basins of Belgium and the Netherlands as a function of late Weichselian morphology, relative sea-level rise and sediment supply. Geologie en Mijnbouw/Netherlands Journal of Geosciences 79, 3-16 (2000).

19. Stive, M. J. F. \& de Vriend, H. J. Modelling shoreface profile evolution. Marine Geology 126, 235248 (1995).

20. Dean, R. G. \& Houston, J. R. Determining shoreline response to sea level rise. Coastal Engineering $114,1-8$ (2016).

21. Cowell, P. J. et al. Shoreface Sand Supply to Beaches. in Proceedings 27th International Conference on Coastal Engineering 2495-2508 (2000).

22. Stive, M. J. F., Roelvink, D. (J )A \& de Vriend, H. J. Large-scale coastal evolution concept. The Dutch coast. Paper No. 9. Proceedings of the Coastal Engineering Conference 2, 1962-1974 (1991).

23. Valiente, N. G., McCarroll, R. J., Masselink, G., Scott, T. \& Wiggins, M. Multi-annual embayment sediment dynamics involving headland bypassing and sediment exchange across the depth of closure. Geomorphology 343, 48-64 (2019).

24. Turner, I. L. et al. A multi-decade dataset of monthly beach profile surveys and inshore wave forcing at Narrabeen, Australia. Scientific Data 3, (2016).

25. Valiente, N. G. et al. Nearshore sediment pathways and potential sediment budgets in embayed settings over a multi-annual timescale. Marine Geology 427, 106270 (2020).

26. Harley, M. D. et al. Extreme coastal erosion enhanced by anomalous extratropical storm wave direction. Scientific Reports 7, (2017).

27. Mortlock, T. R., Goodwin, I. D., McAneney, J. K. \& Roche, K. The June 2016 Australian East Coast Low: Importance of wave direction for coastal erosion assessment. Water 9, 1-22 (2017).

28. Athanasiou, P. et al. Global distribution of nearshore slopes with implications for coastal retreat. Earth System Science Data Discussions 1-29 (2019) doi:10.5194/essd-2019-71.

29. Cooper, J. A. G. \& Pilkey, O. H. Sea-level rise and shoreline retreat: Time to abandon the Bruun Rule. Global and Planetary Change 43, 157-171 (2004).

30. Wainwright, D. J. et al. Moving from deterministic towards probabilistic coastal hazard and risk assessment: Development of a modelling framework and application to Narrabeen Beach, New South Wales, Australia. Coastal Engineering 96, 92-99 (2015). 
31. Anthony, E. J. \& Aagaard, T. The lower shoreface: Morphodynamics and sediment connectivity with the upper shoreface and beach. Earth-Science Reviews 210, 103334 (2020).

32. Mayer, L. et al. The Nippon Foundation-GEBCO seabed 2030 project: The quest to see the world's oceans completely mapped by 2030. Geosciences 8, (2018).

33. Linklater, M. et al. Techniques for classifying seabed morphology and composition on a subtropical-temperate continental shelf. Geosciences (Switzerland) 9, (2019).

34. Diesing, M. et al. Mapping seabed sediments: Comparison of manual, geostatistical, object-based image analysis and machine learning approaches. Continental Shelf Research 84, 107-119 (2014).

35. Traganos, D., Poursanidis, D., Aggarwal, B., Chrysoulakis, N. \& Reinartz, P. Estimating satellitederived bathymetry (SDB) with the Google Earth Engine and sentinel-2. Remote Sensing 10, 1-18 (2018).

36. Thom, B. G. et al. National sediment compartment framework for Australian coastal management. 154, 103-120 (2018).

37. Turner, I. L., Harley, M. D., Almar, R. \& Bergsma, E. W. J. Satellite optical imagery in Coastal Engineering. Coastal Engineering 167, 103919 (2021).

38. Middleton, J. H. et al. Resolution and accuracy of an airborne scanning laser system for beach surveys. Journal of Atmospheric and Oceanic Technology 30, 2452-2464 (2013).

39. Turner, I. L., Harley, M. D. \& Drummond, C. D. UAVs for coastal surveying. Coastal Engineering 114, 19-24 (2016).

40. Wheaton, J. M., Brasington, J., Darby, S. E. \& Sear, D. A. Accounting for uncertainty in DEMs from repeat topographic surveys: Improved sediment budgets. Earth Surface Processes and Landforms 35, 136-156 (2010).

41. Nicholls, R. J., Birkemeier, W. A. \& Lee, G. Evaluation of depth of closure using data from Duck, NC, USA. Marine Geology 148, 179-201 (1998).

42. Hersbach, H. et al. The ERA5 global reanalysis. Quarterly Journal of the Royal Meteorological Society146, 1999-2049 (2020).

\section{Figures}




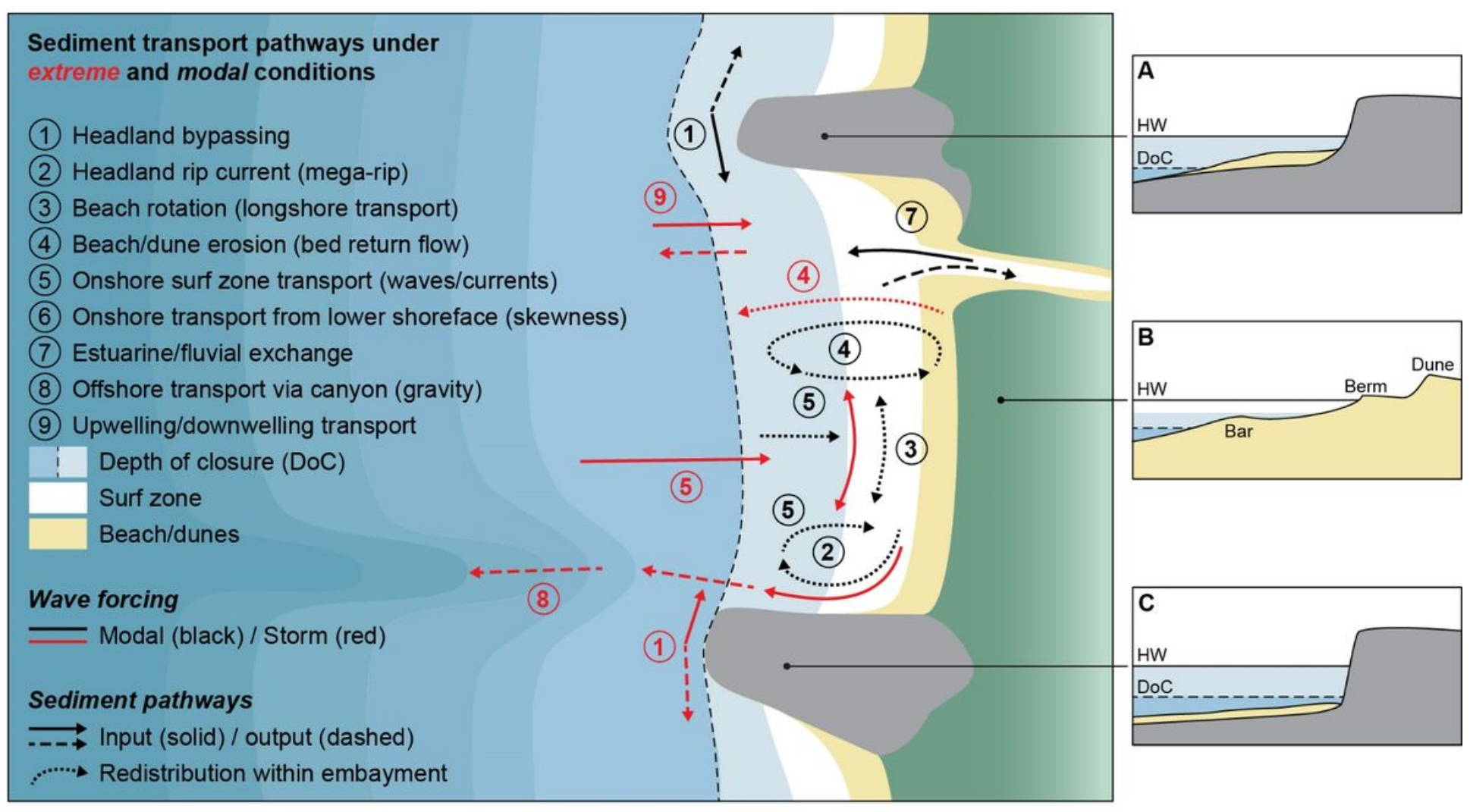

\section{Figure 1}

Key sediment transport pathways under modal and extreme wave conditions on an embayed sandy beach. Red arrows denote sediment transport pathways during storm conditions and black arrows during non-energetic modal conditions. Example cross-sections are illustrated at right. 
a)
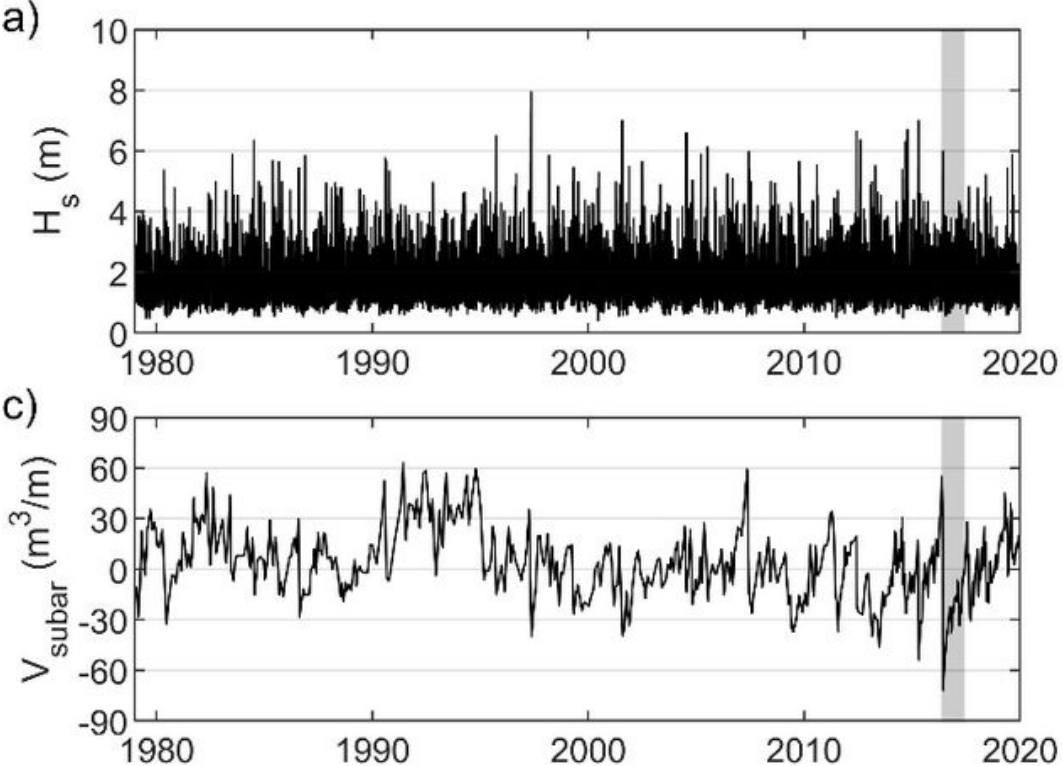

e)

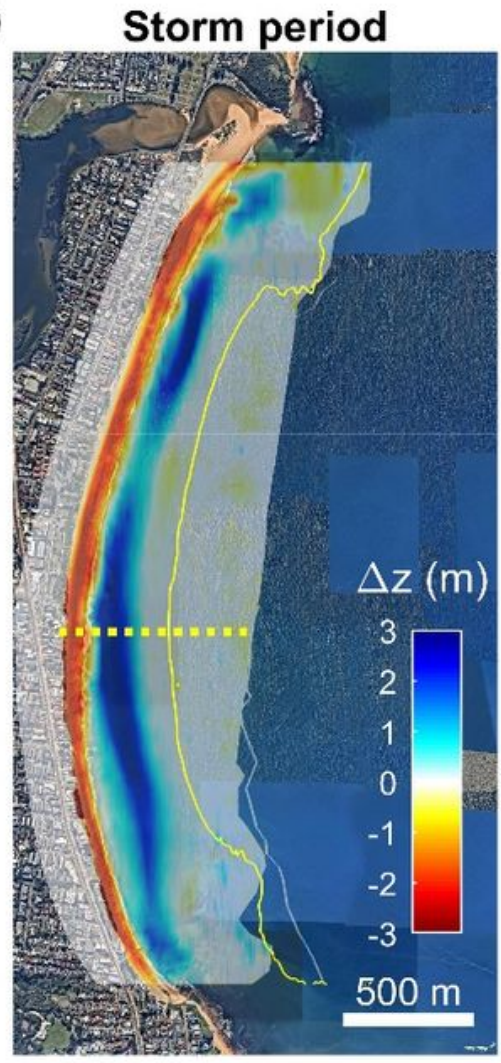

b)

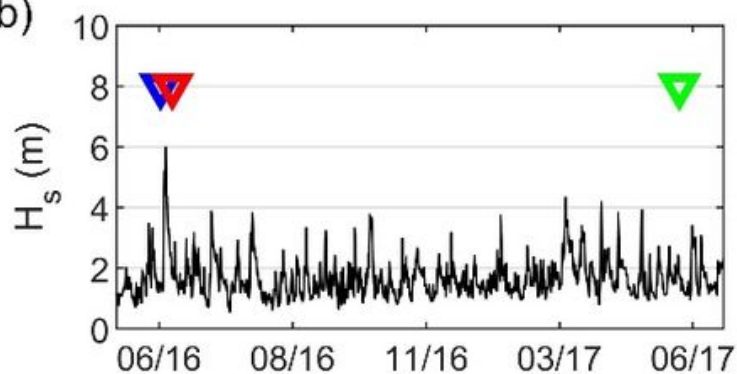

d)

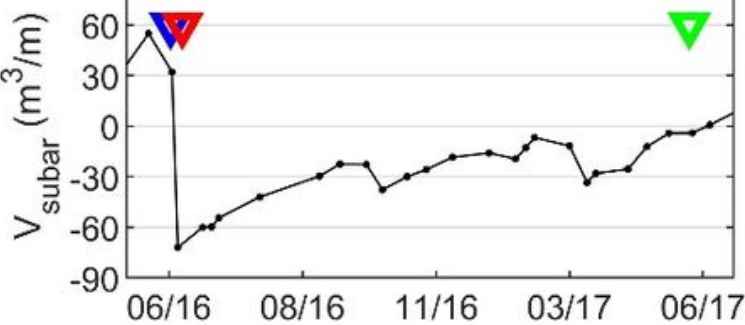

f)

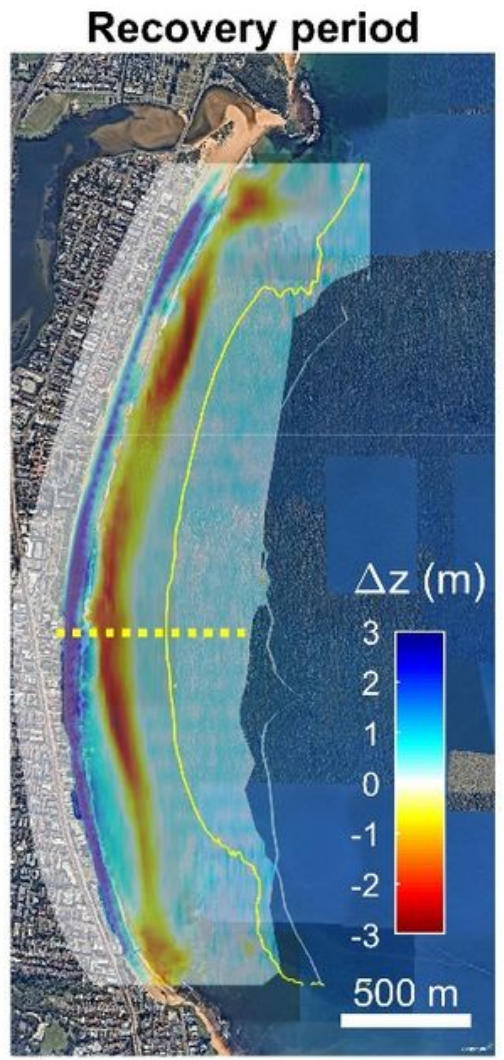

g)

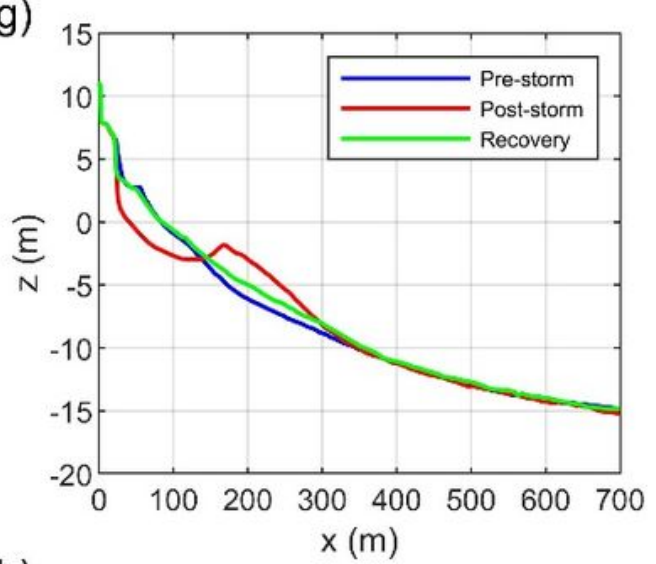

h)

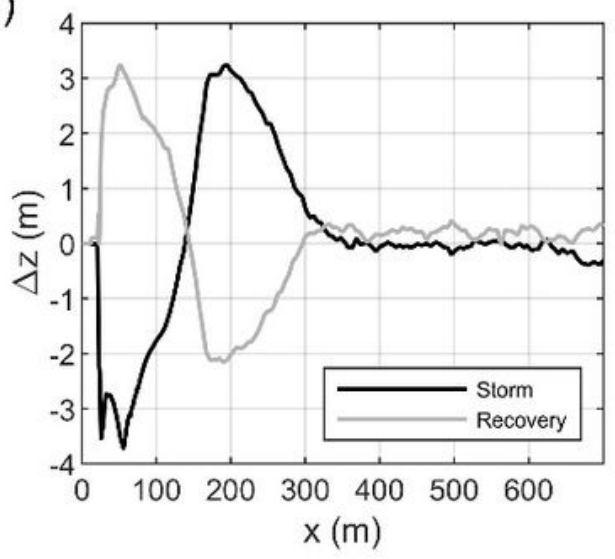

Figure 2

Summary of wave and entire beach variability at Narrabeen Beach, Australia. (a) Deepwater significant wave height for Sydney (1979-2020); and (b) during the storm-recovery sequence. (c) Average subaerial volume change from long-term surveys (1979-2020); and (d) during the storm-recovery sequence. (e) Overall vertical change due to the storm period and f) during the recovery period (Depth of Closure 
indicated by yellow solid lines). (g) A representative cross-shore transect indicating pre-storm, post-storm and recovery morphology; and (h) the vertical change over these two periods.

a)

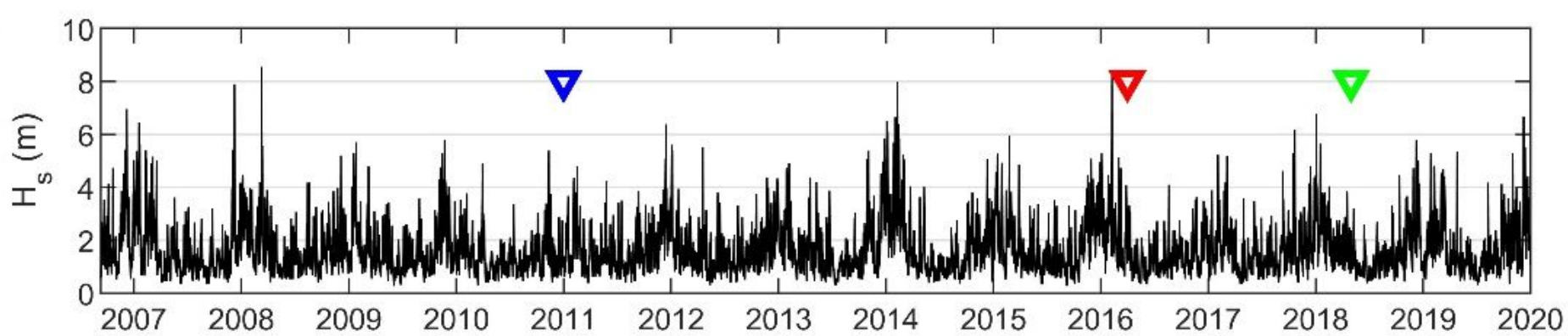

b)

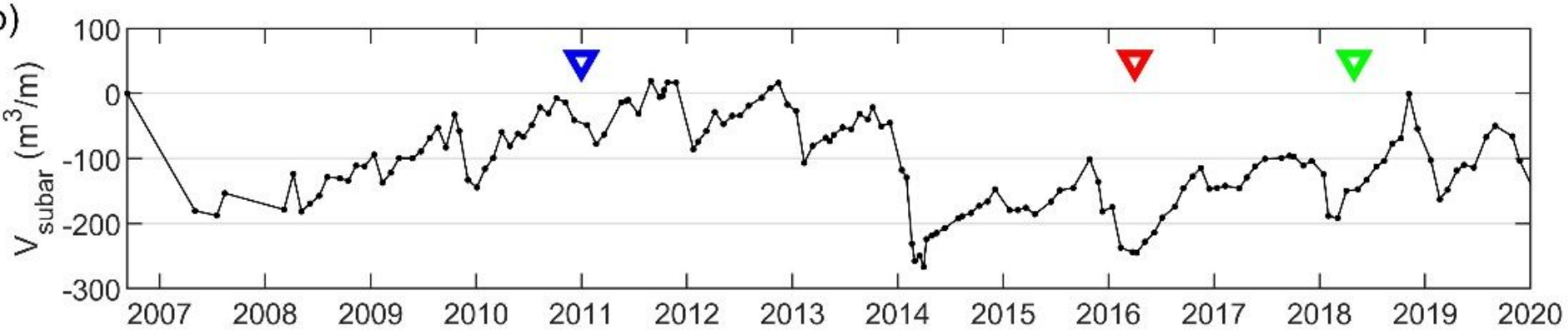

c) Storm period

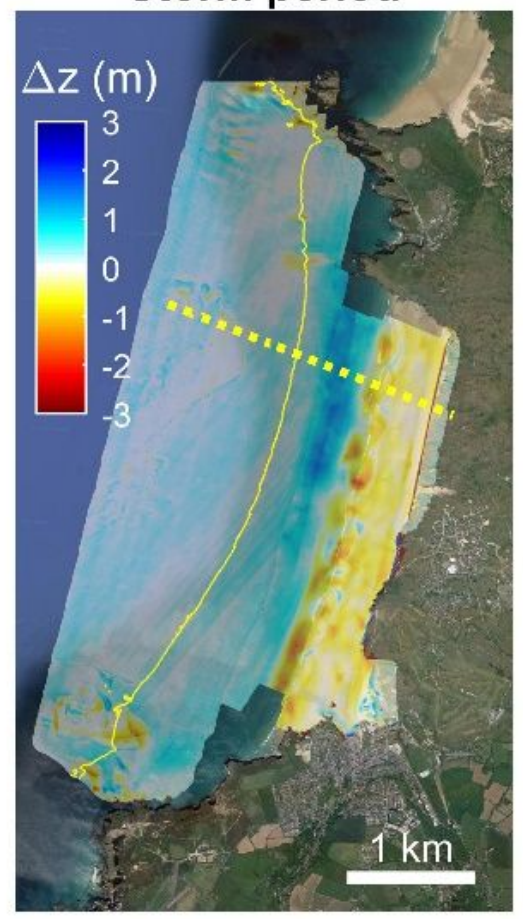

d) Recovery period

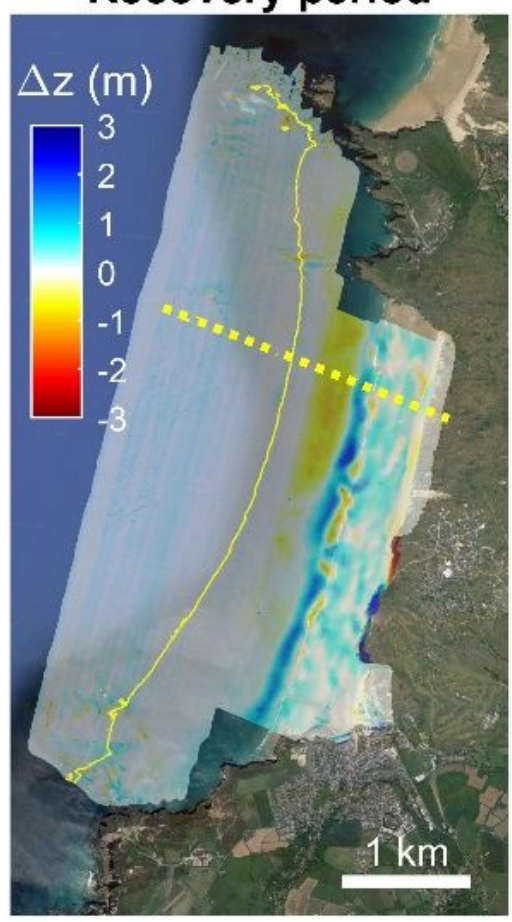

e)

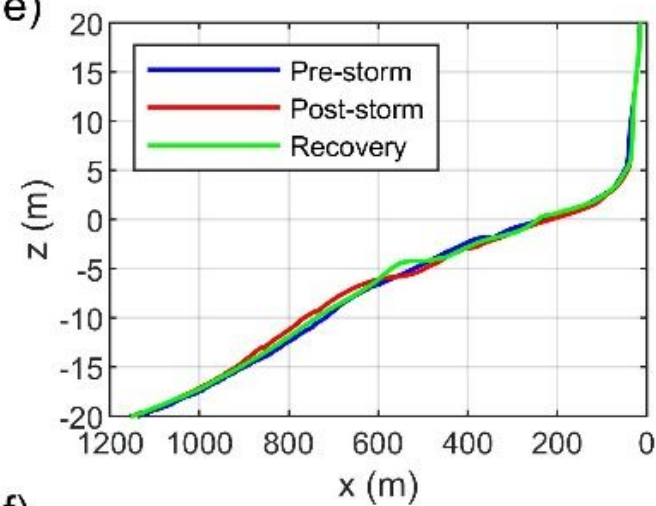

f)

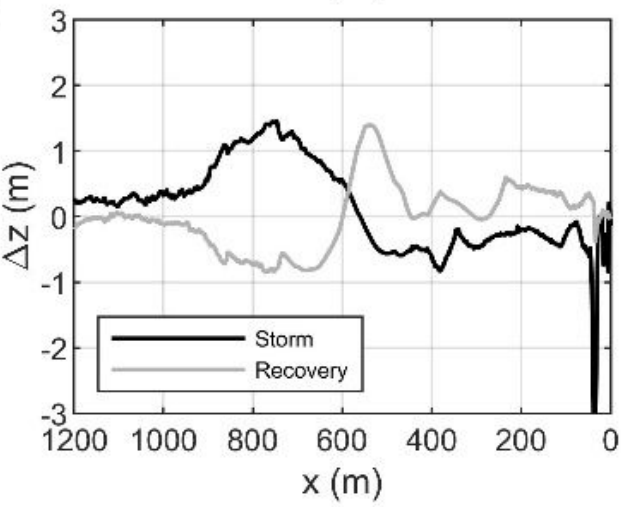

Figure 3

Summary of wave and entire beach variability at Perranporth, UK. (a) Deepwater significant wave height for Perranporth spanning the period of long-term beach surveys (2006-2020). (b) Average subaerial volume change from beach surveys. (c) Overall vertical change during the storm period; and (d) during the recovery period (Depth of Closure indicated by solid yellow line). (e) A representative cross-shore 
transect indicating pre-storm, post-storm and recovery morphology; and (f) the vertical change over these two periods.

a)

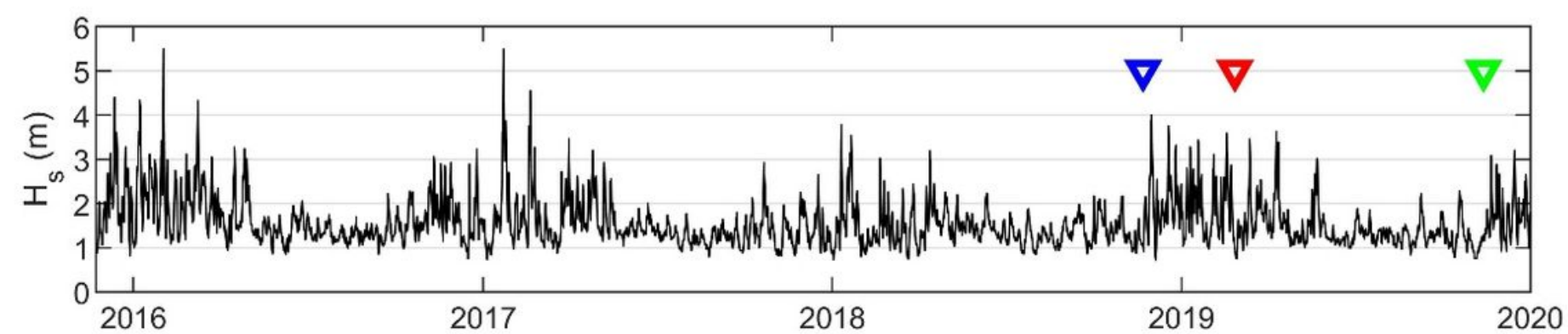

b)

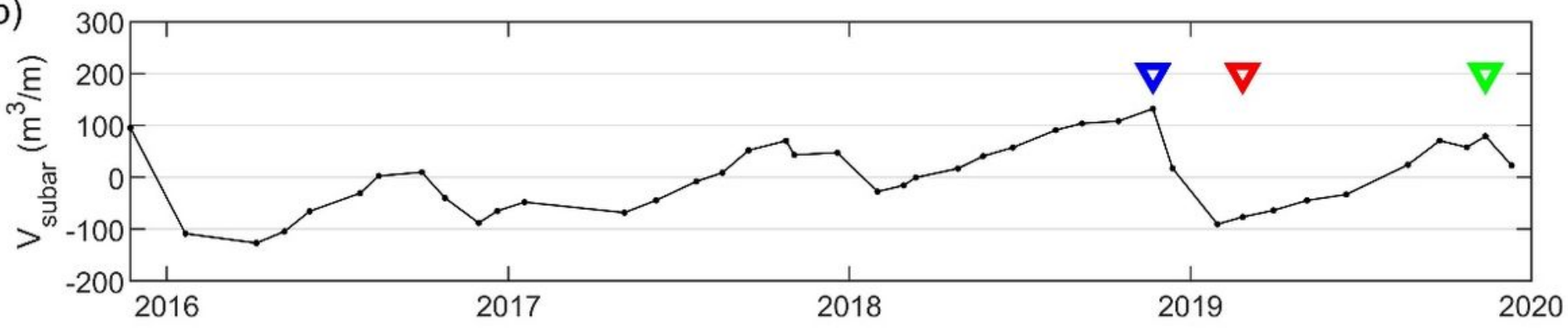

c) Storm period

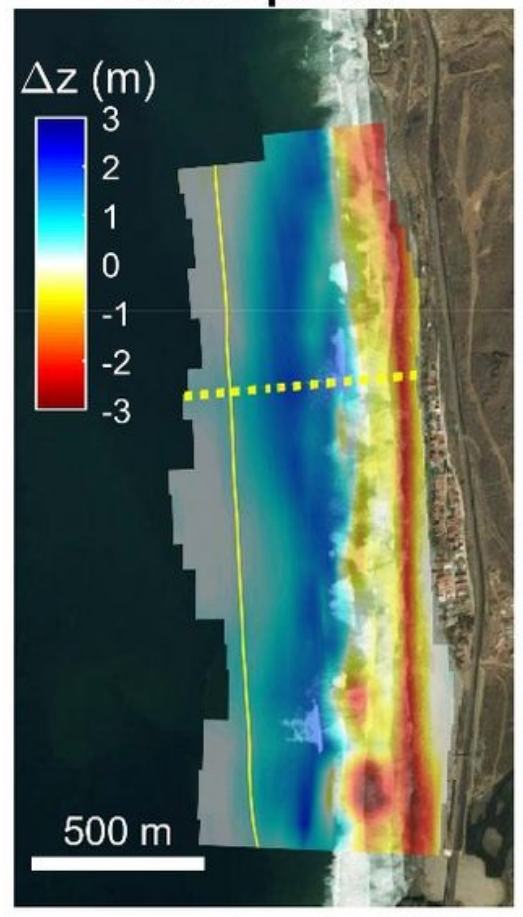

d)

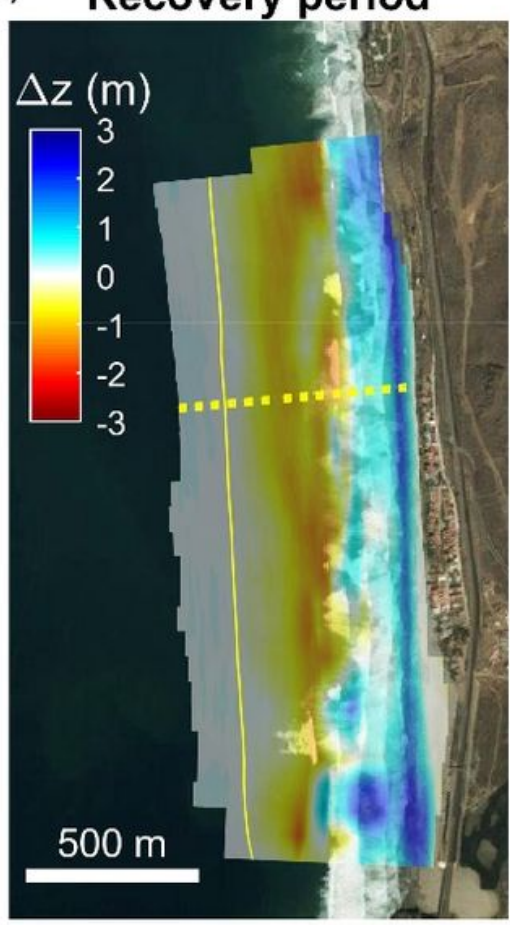

e)

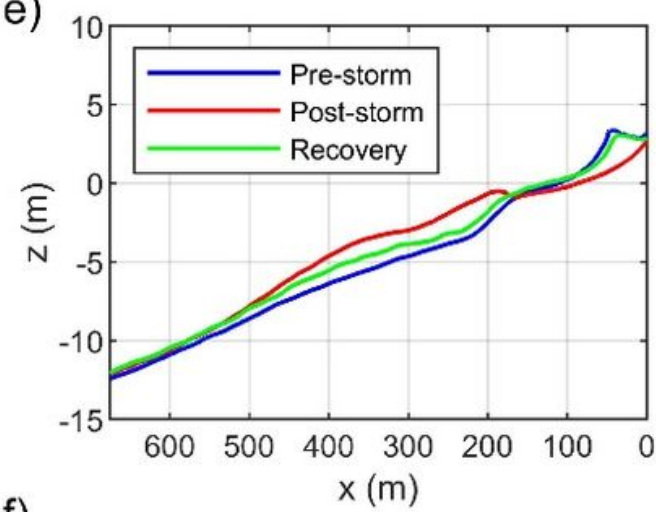

f)

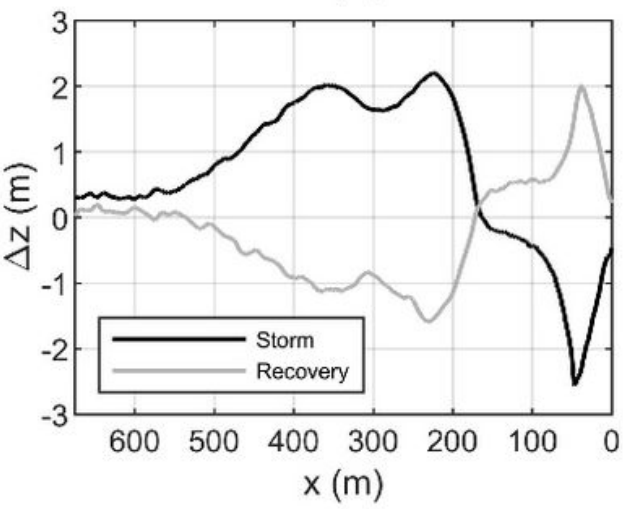

Figure 4

Summary of wave and entire beach variability at La Mision, Mexico. (a) Deepwater significant wave height for La Mision (2015-2020) spanning the period of beach surveys. (b) Average subaerial volume change from beach surveys. (c) Overall vertical change during the storm period; and (d) during the recovery period (Depth of Closure indicated by solid yellow line). (e) A representative cross-shore transect 
indicating pre-storm, post-storm and recovery morphology; and (f) the vertical change over these two periods.
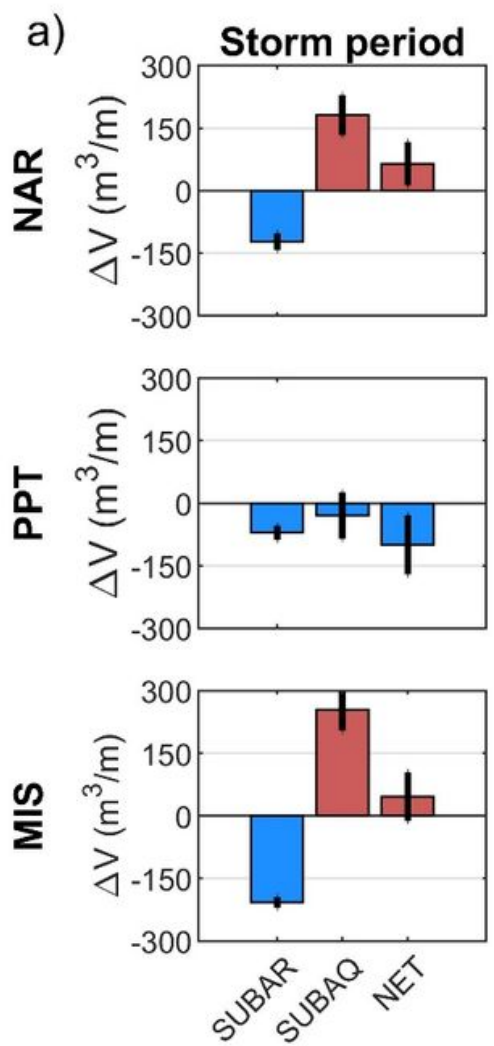
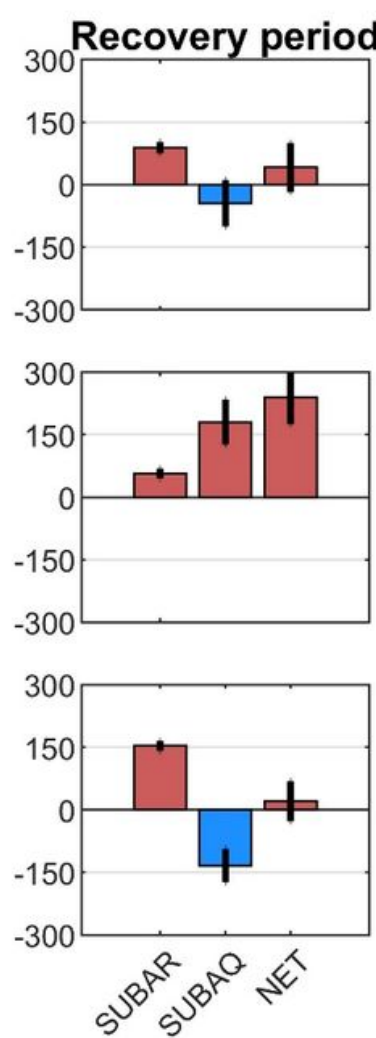
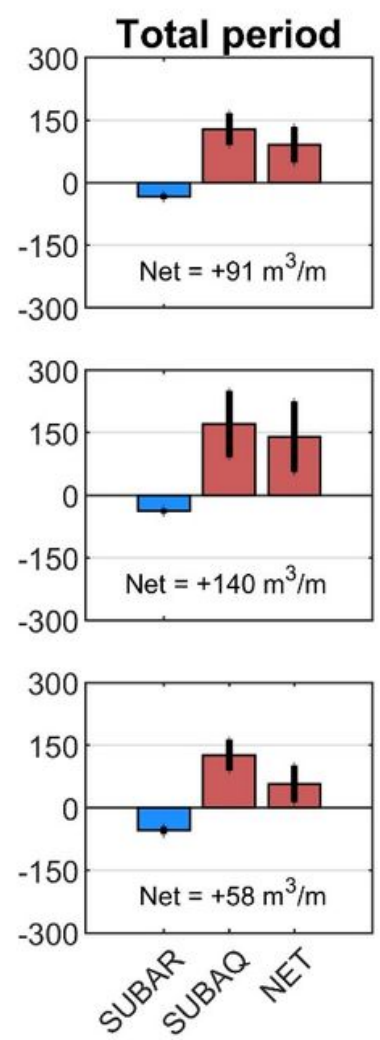

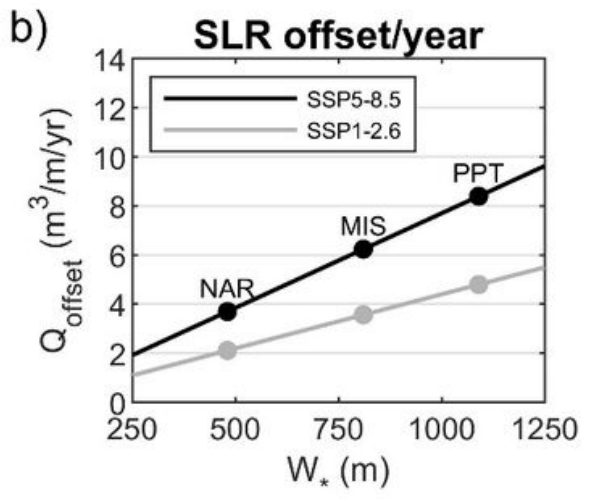

c)

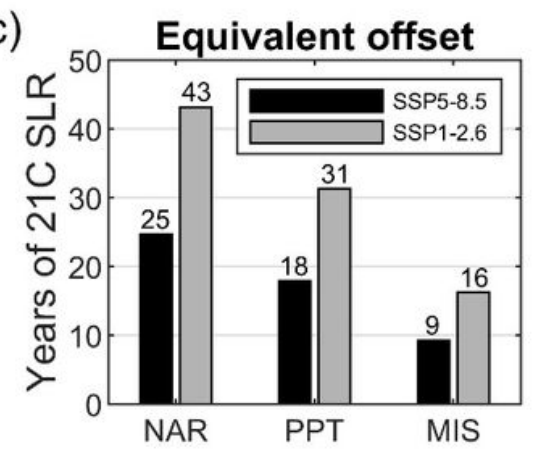

Figure 5

Overall sediment budget changes due to extreme storm-recovery sequences can offset up to decades of theoretical shoreline retreat due to sea-level rise. a) Alongshore averaged volume change (per unit metre) for Narrabeen (NAR), Perranporth (PPT) and La Mision (MIS) beaches are indicated for the storm and recovery periods, separated into subaerial (SUBAR), subaqueous (SUBAQ) and overall net change (NET). b) The annual rate of sediment input required to offset SLR recession over the 21st Century (Qoffset) for the three sites under SSP1-2.6 and SSP5-8.5 scenarios; and c) the equivalent years offset of 21st Century SLR due to the net volumetric gains over each total period. 